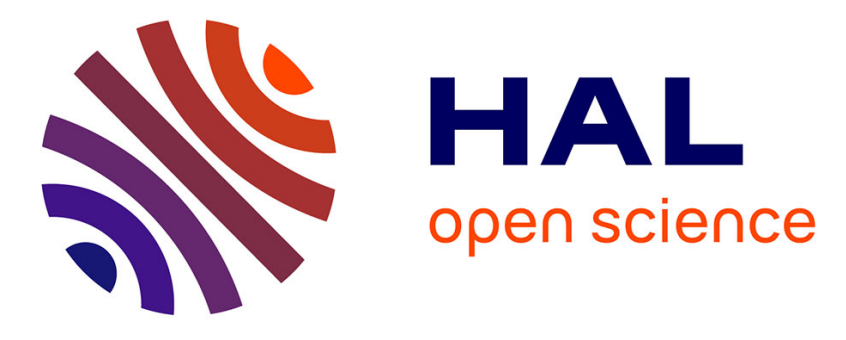

\title{
Spread Mapping of Covid-19 in Morocco Using Geospatial Approach
}

Elhoucein Layati, Abdellah Ouigmane, Marcelo de Carvalho Alves, Bagyaraj Murugesan, Mohamed El Ghachi

\section{- To cite this version:}

Elhoucein Layati, Abdellah Ouigmane, Marcelo de Carvalho Alves, Bagyaraj Murugesan, Mohamed El Ghachi. Spread Mapping of Covid-19 in Morocco Using Geospatial Approach. Journal of Geographical Studies, 2020, 4, pp.34 - 43. 10.21523/gcj5.20040104 . hal-03317784

\author{
HAL Id: hal-03317784 \\ https://hal.science/hal-03317784
}

Submitted on 7 Aug 2021

HAL is a multi-disciplinary open access archive for the deposit and dissemination of scientific research documents, whether they are published or not. The documents may come from teaching and research institutions in France or abroad, or from public or private research centers.
L'archive ouverte pluridisciplinaire HAL, est destinée au dépôt et à la diffusion de documents scientifiques de niveau recherche, publiés ou non, émanant des établissements d'enseignement et de recherche français ou étrangers, des laboratoires publics ou privés. 


\title{
Journal of Geographical Studies
}

Homepage: www.gathacognition.com/journal/gcj5

Original Research Paper

\section{Spread Mapping of Covid-19 in Morocco Using Geospatial Approach}

\section{Elhoucein Layati $^{1}{ }^{*}$, Abdellah Ouigmane ${ }^{2} \odot$, Marcelo de Carvalho Alves ${ }^{3} \odot$ Bagyaraj Murugesan $^{4} \odot$ , Mohamed El Ghachi ${ }^{1}$}

1. Laboratory of Landscape Dynamics, Risks and Heritage, University of Sultan of Moulay Slimane, Beni Mellal, Morocco.

2. Team of Agro-Industrial and Environmental Processes/Team of Applied Spectro-Chemometry and Environment, University of Sultan of Moulay Slimane, Beni Mellal, Morocco.

3. Department of Agricultural Engineering, Federal University of Lavras, University Campus, P. O. Box- 3037, 37200-000, Lavras, Minas Gerais, Brezil.

4. Department of Geology, College of Natural and Computational Sciences, Debre Berhan University, P.O.Box 445, Debre Berhan, Ethiopia.

\begin{abstract}
Most of the people infected in Morocco are triggered by the outbreak of COVID-19. The number of affected cases is currently rising day by day. As of July $16^{\text {th }}, 2020$, In Morocco, 15,165 cases were tested positive for COVID-19, including 239 deaths and 11,417 patients cured the highest number of Corona virus cases reported as Ministry of Health Department in Morocco. The COVID-19 virus threatens the health, economy, development and social life of individuals. The city needs to be conscious of the fight against this epidemic. GIS technology has played an important role in many aspects, including geospatial perception, geostatistical simulation and spatial knowledge enabling decision-making, mitigation and prediction including COVID-19. GIS has evolved reasonably rapidly and has a full technical route for data processing, modeling and map creation. However, in the battle against the popular endemic, the key challenge is to find ways of controlling conventional technological methods and to increase the quality and accuracy of the knowledge provided for social management. As a consequence, IDW and computational approaches are used to forecast potential cases in the region. Prediction of different parameters existing confirmed events, death and recovery of COVID-19. See reports have been used to take proactive measures in order to penetrate regions. The suggested method of understanding is effective within a certain context and would be a valuable tool for both governments and health authorities.
\end{abstract}

\begin{tabular}{l} 
Article history \\
\hline Received: 21 July 2020 \\
Revised: 21 September 2020 \\
Accepted: 22 September 2020 \\
Keywords \\
\hline Covid-19; \\
GIS; \\
Inverse Distance Weighted (IDW); \\
Morocco; \\
Spatial Distribution. \\
Editor(s) \\
\hline
\end{tabular}

M. A. Siddiqui

Vijay Bhagat

\section{INTRODUCTION}

Since December 31, 2019, the Centers for Disease Control and Prevention and Chinese health authorities have complied with the emergence of the new coronavirus of unknown origin in Wuhan, China. The disease has been named by Coronavirus Disease "Covid-19" (CDC, 2020). Epidemiologists, infectiologists and biologists are analyzing the data collected from the first diseases in China. They have detected that this virus manifests itself as a pneumonic syndrome (Bouaré, 2020; CCDCP, 2020). On February
28, 2020, the UN Secretary General called on governments to take preventive measures against the spread of COVID-19, which continues to spread throughout the world, it has contaminated more than 13,604,293 people and 585,611 decided until July 16, 2020 (WHO, 2020). Infected cases have been registered in all continents; Africa (540,682 cases), Americas (7,149,551 cases), Eastern Mediterranean (1,346,708 cases), Europe (3,008,439 cases), South-East Asia (1,306,832 cases) and Western Pacific (252,081 cases).

\footnotetext{
Author's address for correspondence

Laboratory of Landscape Dynamics, Risks and Heritage, University of Sultan of Moulay Slimane, Beni Mellal, Morocco. Tel.: +212 682688849

E-mails: houssa8layati@gmail.com (E. Layati -Corresponding author); ouigmaneabdellah@gmail.com (A. Ouigmane), marcelocarvalhoalves@gmail.com (M. de C.Alves),geobagya25@gmail.com (B. Murugesan), elghachi_mohamed@yahoo.fr (M. Ghachi). 
Most of the recorded deaths are in the United States of America (135,807 deaths), Brazil (74,133 deaths), The United Kingdom (45,053 deaths) and Italy $(34,997$ deaths). In Morocco, 15,165 cases were tested positive for COVID-19, including 239 deaths and 11, 417 patients cured (MMH, 2020).

In recent years, Geographic Information System (GIS), mapping and geostatistics have been used to assist in the interpretation and analysis of the geographic distribution of diseases in areas at risk. These tools play a very important role in the prevention and control of spread of epidemic (Jerrett et al., 2010; CAICT, 2020; Maged et al., 2020; Zhou et al., 2020). GIS plays a very important role in the field of health, monitoring the spread of a disease in a region and the spatial and temporal follow-up of this transmission (Ding et al., 2011; Shaw, 2012; Cheng et al., 2012; Bhunia et al., 2013). Specialists and GIS experts have confirmed that there is complementarity and congruence between health data and map processing (Brooker et al., 2009). GIS facilitates the representation, analysis and characterization of the spatial (spatiotemporal) component of health phenomena. In general, GIS technology is opening up new opportunities for epidemiologists to study and identify health black spots (Helene et al., 2010; Bagyaraj et al., 2020). They also hold a huge array of resolution options, which can be beneficial for prevention and health empowerment initiatives, disease care and proper adjustment (Lyseen et al., 2014). Spatial geostatistics has been applied in various fields such as, hydrology (Schreider et al. 1997; Kawo and Karuppannan, 2018), climatology (Kurtzman and Kadmon, 1999; Anis and Saeed, 2006), agriculture (Robinson and Metternicht, 2003; Quenum, 2009) and more recently in epidemiology (Jayakumar and Malarvannan, 2013; Qayssar et al., 2018; Bagyaraj et al., 2020). Spatial interpolation methods can be broadly classified into two categories:

1. Deterministic/empirical methods (Willmott and Matsuura, 1995; Kurtzman and Kadmon, 1999): These are based on purely mathematical properties that express either a weighting factor for training values or a trend surface: The Inverse Distance Weighted (IDW), Global Polynomial Interpolation (GPI), Radial Basis Functions (RBF) and Local Polynomial Interpolation (LPI).

2. Probabilistic methods (Bronowicka et al., 2019): Stochastic methods (geostatistics), they are based on the principle of spatial autocorrelation which recommends that close observations in space have similar characteristics, they are distinguished by the calculation of associated estimation errors (Krige, 1966; Matheron, 1963; Holdaway, 1996; Laborde, 2000)- Kriging and Cokriging; Areal Interpolation (AI); Empirical Bayesian Kriging (EBK).

The purpose of this work is to demonstrate the contribution of GIS and geospatialization to the distribution and mapping of COVID-19 using ArcGis and the geostatistical analyst extension.

\section{DATA AND METHODS}

Historical data of COVID-2019 infected persons (16 July 2020) were collected and used in this study, from the official website of the Johns Hopkins University. (Benvenuto et al., 2020) and from the official coronavirus monitoring website in Morocco (WHO, 2020; MMH, 2020).

Inverse distance weighting (IDW) method is the most widely used in the GIS program to map and spatialize the spread of vector-borne diseases. This modern approach helps decision makers in surveillance since the IDW method is accurate and more precise (Childs, 2004; Katharina et al., 2011; Kheirandish et al., 2012; Bhunia et al., 2013; Bao et al., 2014; Kawo and Karuppannan, 2018; Qayssar et al., 2018; Bagyaraj et al., 2020). The main factor affecting the accuracy of the IDW is the value of the power $p$ (Burrough and McDonnell, 1998). Thus, the relevance and accuracy of the IDW is influenced by neighborhood size and the number of neighbors.

The IDW is expressed mathematically (equation 1) according to Johnston et al. (2001):

$$
Z_{0}=\frac{\sum_{i=1}^{N} z_{i} \cdot d_{i}^{-n}}{\sum_{i=1}^{N} d_{i}^{-n}}
$$

where,

$Z_{0}$ is the estimation value of variable $\mathrm{z}$ in point 1 ;

$Z_{i}$ is the sample value in point 1 ;

$d_{i}$ is the distance of sample point to estimated point;

$N$ is the coefficient that determines weigh based on a distance;

$n$ is the total number of predictions for each validation cases.

\section{STUDY AREA}

On the northwestern tip of Africa, Morocco opens up to both the Atlantic and the Mediterranean, between the $37^{\text {th }}$ and $21^{\text {st }}$ parallels. It is bounded to the north by the Strait of Gibraltar and the Mediterranean Sea, to the south by Mauritania, to the east by Algeria and to the west by the Atlantic Ocean. It has a total area of 710,850 $\mathrm{km}^{2}$ (Figure 1). The administrative capital is Rabat and the economic capital is the largest city Casablanca. The population of Morocco is spread over 1538 communes: 256 urban and 1282 rural. Morocco is divided into 12 regions. Its population is nearly 38 million inhabitants $(\mathrm{CPH}, 2014)$. The distribution of this population is very uneven in Morocco: nearly $90 \%$ of the inhabitants live in the north of the country (Figure 1 and Table 1). The three main sectors of economic activity in Morocco are agriculture, industrial and commercial services. 


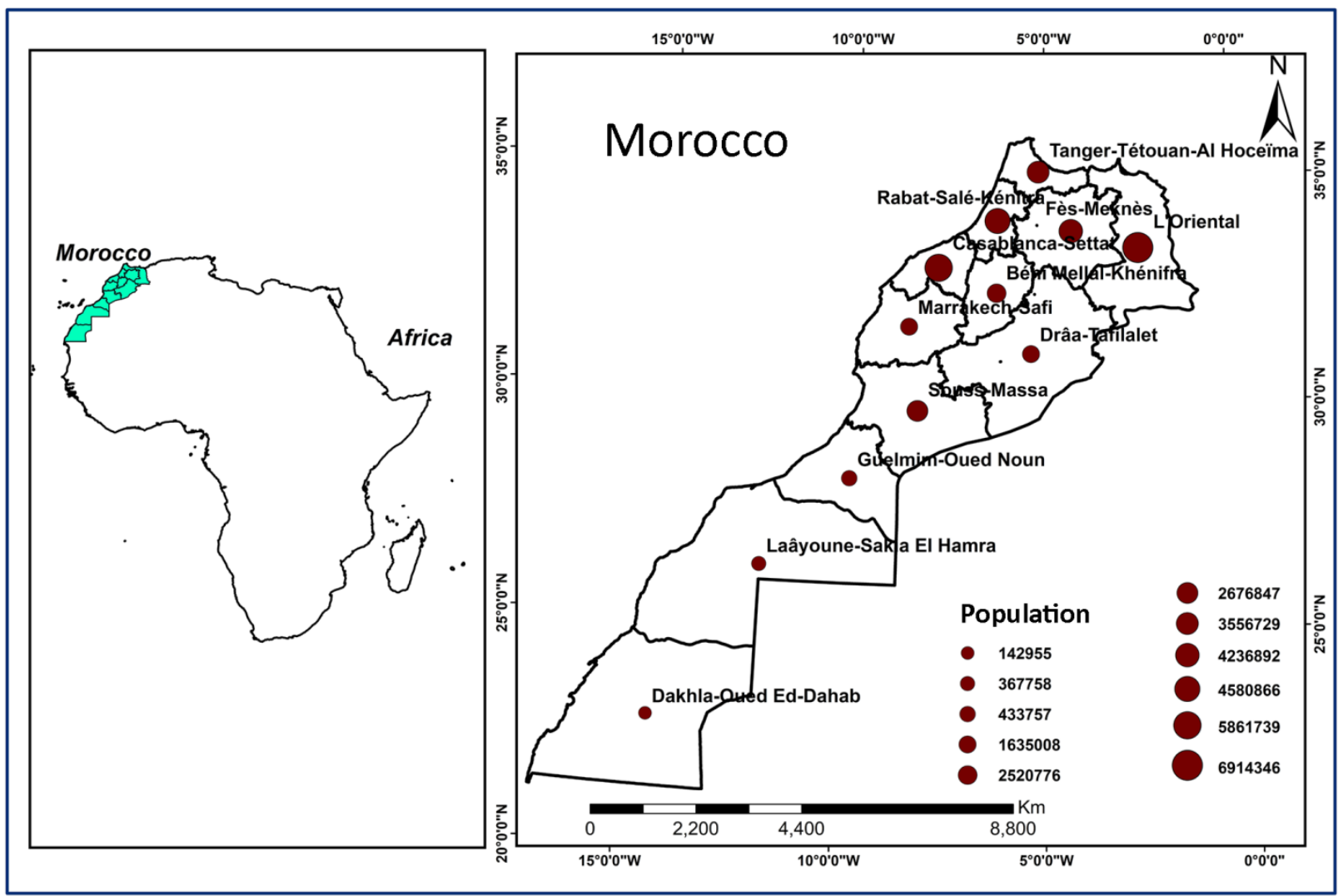

Figure 1. Study area with distribution of population in Morocco

Table 1. Region-wise population

\begin{tabular}{lcc}
\hline & \multicolumn{2}{c}{ Population (2014) } \\
\cline { 2 - 3 } & Persons & $\%$ \\
\hline Tanger-Tétouan-Al Hoceïma & 3556729 & 10,5 \\
L'Oriental & 6914346 & 21,8 \\
Fès-Meknès & 4236892 & 12,5 \\
Rabat-Salé-Kénitra & 4580866 & 13,5 \\
Béni Mellal-Khénifra & 2520776 & 7,4 \\
Casablanca-Settat & 5861739 & 20,2 \\
Marrakech-Safi & 4520569 & 13,3 \\
Drâa-Tafilalet & 1635008 & 4,8 \\
Souss-Massa & 2676847 & 7,9 \\
Guelmim-Oued Noun & 433757 & 1,2 \\
Laâyoune-Sakia El Hamra & 367758 & 1,0 \\
Dakhla-Oued Ed-Dahab & 142955 & 0,4 \\
Total & 37448242 & 100 \\
\hline
\end{tabular}

Source: CPH, 2014 


\section{RESULTS AND DISCUSSIONS}

\subsection{Evolution of COVID-19 Disease}

Morocco has recorded 15,165 cases of COVID-19 contamination since the beginning of the pandemic on 2 March 2020, including 239 deaths and 11, 417 people cured, while the number of cases excluded after negative results amounts to 940,132 (Table 2) (MMH, 2020). According to the Minister of Health, the two most affected regions remain "Casablanca-Settat", "Marrakech-Safi" and "Tanger-Tetouan-Al Hoceïma", "Rabat-Sale-Kenitra", with more than $75.34 \%$ of confirmed cases.

\subsection{Evolution of COVID-19 for Every 14 Days}

People can become infected with Coronavirus disease (Covid-19) because of other people infected with this virus. The disease may not be spread from person to person. The duration of onset of symptoms varies from one day to 14 days (Victor, 2020; Tian et al., 2020; WHO, 2020). The map (Figure 2) shows the evolution of COVID-19 infections every 14 days.

From the map (Figure 4), it can be seen that the evolution of confirmed cases is regular according to the 14 days period notably in the regions of CasablancaSettat, Marrakech-Safi, Tanger,-Tétouan-Al Hoceïma and Rabat-Sale-Kenitra. On the other hand, the evolution is irregular in the region of Fes-Meknes and Daraa-Tafillat, where the appearance of cases increased intensely during the eighth 14 days period. This can be explained by a sudden lack of compliance with containment in these two regions. Concerning the rest of the regions in Morocco, it is noted that the evolution of the coronavirus is almost stable in fairly low values.

\subsection{Exploratory Analysis}

According to Table 3, it can be noticed that the distribution of Covid-19 in Morocco is characterized by an asymmetry coefficient (S) equal to (0.65242) which is greater than 0 and therefore an asymmetry towards the right and by a flattening coefficient $(\mathrm{K})$ equal to (1.9468) which is less than 3 and therefore the distribution of Covid-19 is playkurtotic (Zhiqiang et al., 2008).

\subsection{Distribution of COVID-19}

In order to predict the spread of diseases in Morocco, interpolation using the IDW was obtained. The map presented in figure 3 shows the extended disease area in the country. The pattern of COVID-19 diseases in the six classes is as follows: 17 to 400,400 to 800,800 to 1200,1200 to 1600,1600 to 2000 and > 2000 (Figure 3 ). It is noted that the areas with a high spread of the virus are the North-West and the North of Morocco. These areas are characterized by a higher population density (Table 1) (CPH, 2014) and the main cities in these regions are Casablanca, Marrakech, Rabat and Tanger, which are characterized by economic and tourist activity. In these regions more care is being taken to control the spread of the disease. On the other hand, the other regions with weak economic activities are characterized by weak evolution of confirmed (Ouhsine et al, 2020). The spread tends towards the West, which is limited by the Atlantic Ocean. In the other part, it is noted that the spread decreased further towards the south of Morocco which has a Saharan character.

Table 2. Distribution of confirmed cases, decided and recoveries of COVID-19 in Morocco

\begin{tabular}{lccc}
\hline \multirow{2}{*}{ Name of the region } & \multicolumn{3}{c}{ Cases } \\
\cline { 2 - 4 } & Confirmed & Decided & Recovered \\
\hline Tanger-Tétouan-Al Hoceïma & 2966 & 56 & 2269 \\
L'Oriental & 248 & 8 & 184 \\
Fès-Meknès & 1697 & 29 & 1264 \\
Rabat-Salé-Kénitra & 2032 & 12 & 1864 \\
Béni Mellal-Khénifra & 165 & 7 & 101 \\
Casablanca-Settat & 3713 & 53 & 2628 \\
Marrakech-Safi & 2714 & 58 & 1960 \\
Drâa-Tafilalet & 586 & 5 & 586 \\
Souss-Massa & 97 & 7 & 85 \\
Guelmim-Oued Noun & 135 & 3 & 72 \\
Laâyoune-Sakia El Hamra & 795 & 1 & 394 \\
Dakhla-Oued Ed-Dahab & 17 & 0 & 10 \\
\hline
\end{tabular}

Source: Ministry of Health, Morocco (16 ${ }^{\text {th }}$ July 2020). 


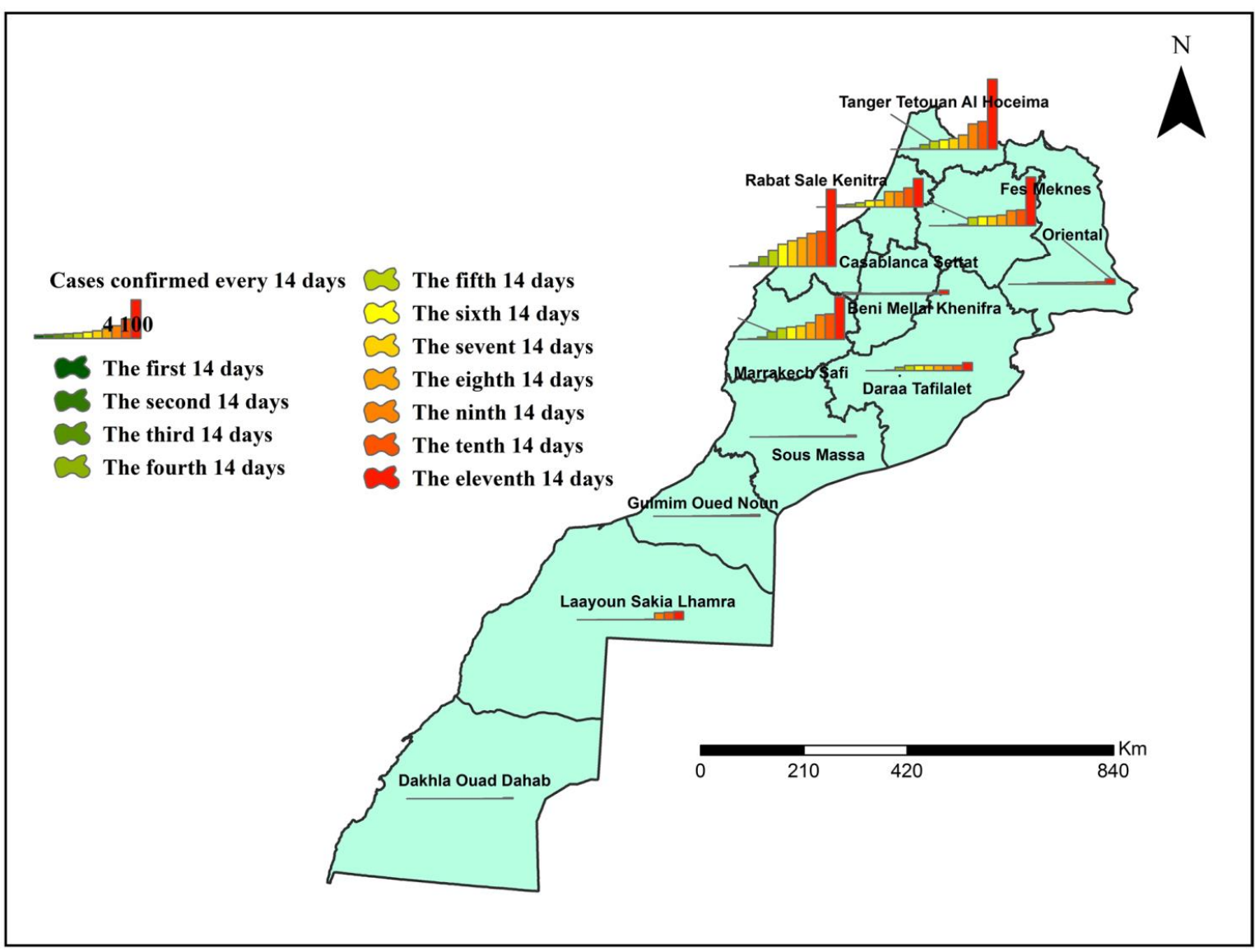

Figure 2. Time series of Covid-19 disease cases for every 14 days

Table 2. Descriptive Statistics of Covid-19 distribution

\begin{tabular}{lccc}
\hline Count & 12 & Skewness & 0.65242 \\
\hline Minimum & 17 & Kurtosis & 1.9468 \\
Maximum & 3713 & 1-St Quartile & 150 \\
Mean & 1263.8 & Median & 690.5 \\
Standard Deviation & 1310.3 & 3-rd Quartile & 2373 \\
\hline
\end{tabular}

The figure 4 and 5 shows the distribution of the prediction of death and recovery of COVID-19, respectively in Morocco. Regarding deaths, the area around Casablanca and Marrakesh is the most dangerous while the area around the city of Oujda, South and Southeast is the lowest in terms of deaths. Studies show that temperature has an impact on deaths and confirmed patients, indeed temperatures are low in the North of Morocco compared to the South (Shrikant et al., 2020). In terms of curing, the region around Casablanca-Setta and Tanger-Tetouan-Al Hoceïma is the most cured and the central and northeast regions of the country are moderately cured and cases are less cured in the south. The spread of certain diseases depends on several parameters related to physiology and environmental conditions. So far no treatment has been found for COVID-19, therefore such interpolation can help the authorities to take precautionary and preventive measures against this disease. WHO announced that the emergence of the new coronavirus disease (COVID-19) is a pandemic and reiterated its call for immediate action by governments to intensify their response to diagnose, identify and mitigate the spread to save lives. Such a study was conducted in India using the IDW method to prevent the spread and distribution of COVID-19 cases (Bagyaraj et al., 2020). In this context, the Government of Morocco will take all necessary precautions to ensure that we are well prepared to face the challenge and threat posed by the growing corona virus pandemic COVID-19. 


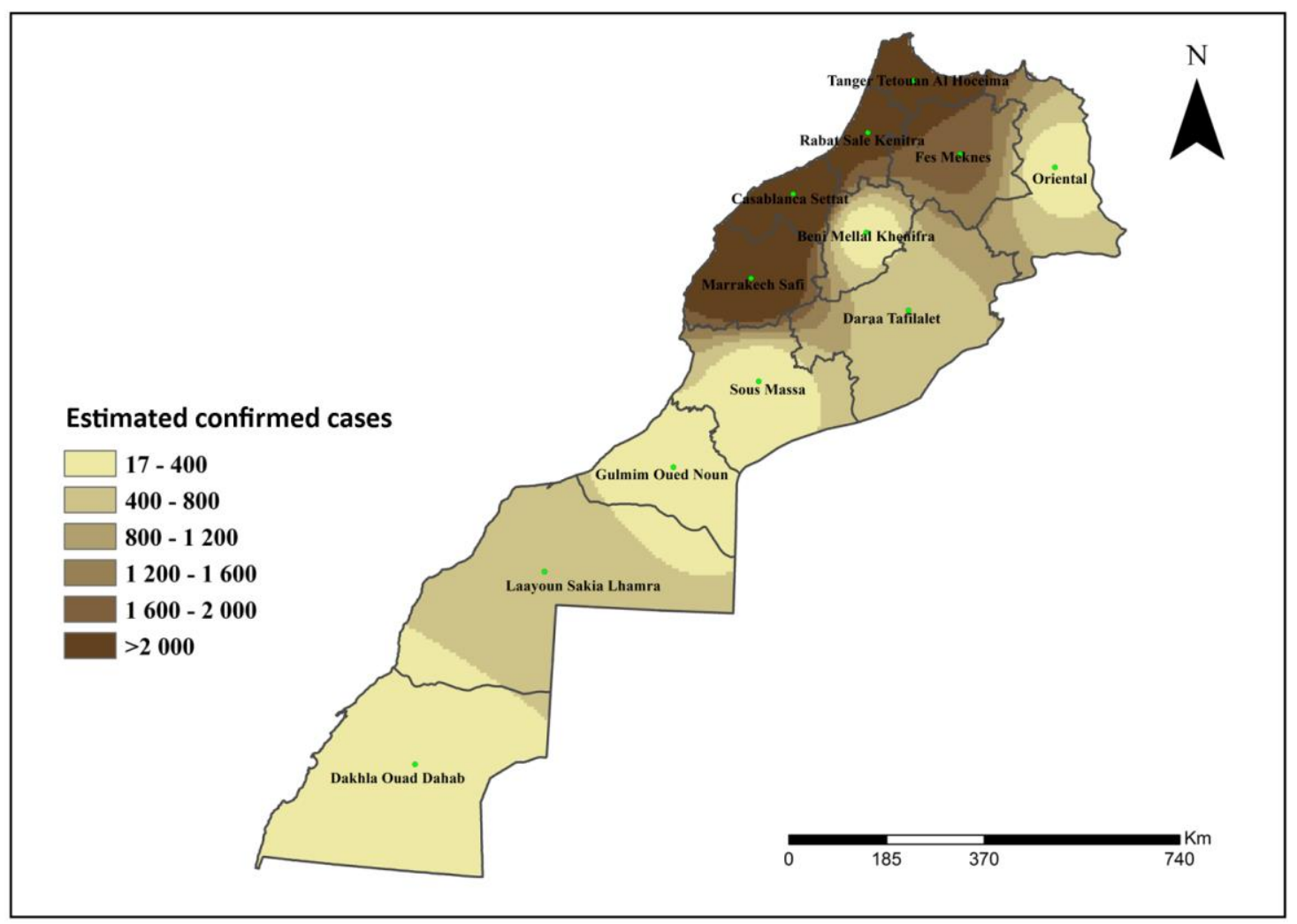

Figure 3. Distribution of estimated confirmed patients

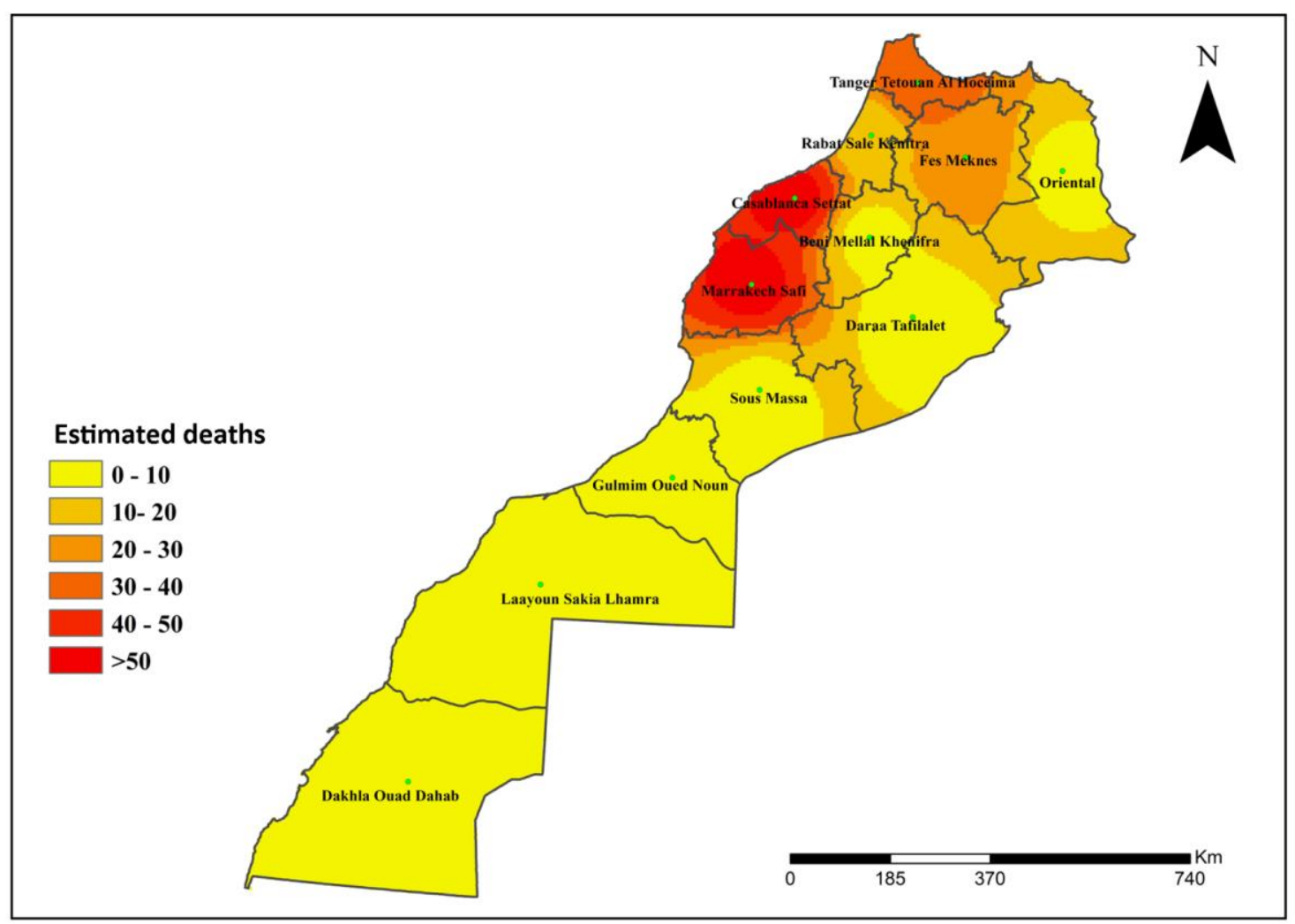

Figure 4. COVID-19: Distribution of estimated deaths 


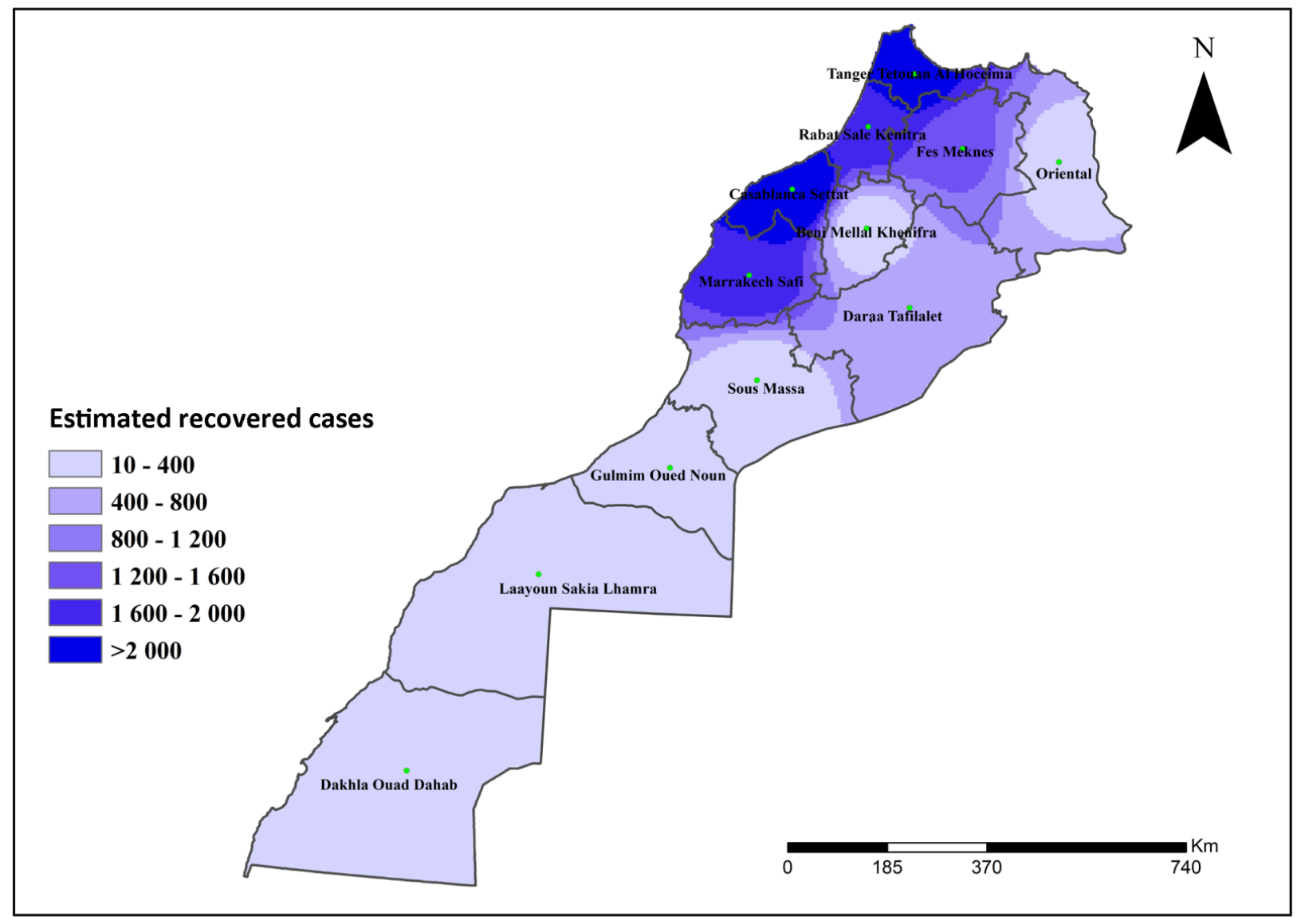

Figure 5. COVID-19: Distribution of estimated recovered

\section{CONCLUSION}

The objective of this study was to describe the spread of Covid-19 in Morocco. The use of spatial technology and GIS play an important role in showing, simplifying and measuring the epidemiological situation of virus disease surveillance and prediction in the study area. The methodology followed in the present research, firstly, data were collected to create a database, and secondly, IDW was chosen to describe the spread of Covid-19, identifying high and low risk areas. Regions of Casablanca-Settat, Marrakech-Safi, Tangier Tetouan Al Houcima, Rabat-Salé-Kenitra and Fes-Meknes were the most affected by COVID-19. On the other hand, the results for the other regions showed that they were less infected thanks to the actions of citizens and respect for lockdown. It was noted that the areas with a high spread of the virus were the North-West and the North of Morocco. Regarding deaths, the area around Casablanca and Marrakesh was the most dangerous while the area around the city of Tanger, South and Southeast is the lowest in terms of deaths.

\section{ACKNOWLEDGMENTS}

The authors would like to thank the Ministry of Health, Morocco for given data relating to the spread of COVID-19 in Morocco.

\section{ABBREVIATIONS}

CAICT: China Academy of Information and Communications Technology; CCDCP: Chinese Center for Disease Control and Prevention; CDC: Center for Disease Control and Prevention; COVID-19: Coronavirus Disease-2019; CPH: Census of Population and Housing; GIS: Geographic Information System; IDW: Inverse Distance Weighting; MMH: Moroccan Ministry of Health; UN: United Nations; WHO: World Health Organization.

\section{CONFLICT OF INTEREST}

The authors declare no conflict of interest.

\section{REFERENCES}

Anis, R..F, and Saeed, R. A., 2006. Comparison of different interpolation methods for temperature mapping in Pakistan. The 2nd International Conf. on Water Resources \& Arid Environment. 
Bagyaraj, M., Shankar, K., Alemayehu, T. M., Muthukumarasamy, R. and Gnanachandrasamy, G., 2020. Distribution and trend analysis of COVID-19 in India: Geospatial approach. J. Geographical Studies, 4(1), 1-9. DOI: https://doi.org/10.21523/gcj5.20040101

Bao, C., Liu, W., Zhu, Y., Liu, W., Hu, J., Liang, Q., Cheng, Y., Wu, Y., Yu, R., Zhou, M., Shen, H., Chen, F., Tang, F. and Peng Z., 2014. The spatial analysis on hemorrhagic fever with Renal Syndrome in Jiangsu Province, China Based on Geographic Information System. PLoS ONE 9(9): e83848. DOI: https://doi.org/10.1371/journal.pone.0083848

Benvenuto, D., Giovanetti, M., Vassallo, L., Angeletti, S. and Ciccozzi, M., 2020. Application of the ARIMA model on the COVID- 2019 epidemic dataset. Data in brief 29, 105340. DOI: https://doi.org/10.1016/j.dib.2020.105340

Bhunia, G. S., Kesari, S., Chatterjee, N., Kumar, V. and Das, P., 2013. Spatial and temporal variation and hotspot detection of kala-azar disease in Vaishali district (Bihar), India. BMC infectious diseases, 13(1), 64. DOI: https://doi.org/10.1186/1471-2334-13-64

Bouaré, N., 2020. La maladie de SARS-CoV2 (COVID-19): Une réflexion contributive à la prévention et/ou la riposte contre la pandémie. Potential Epidemiological Diseases Prevention Project. DOI: https://doi.org/10.13140/RG.2.2.27071.25769

Bronowicka, U. M., Mielniczuk, J., Obroślak, R. and Przystupa, W., 2019. A comparison of some interpolation techniques for determining spatial distribution of nitrogen compounds in groundwater. International Journal of Environmental Research, 13:679-687. DOI: https://doi.org/10.1007/s41742-01900208-6

Brooker, S., Kabatereine, N. B., Smith, J. L., Mupfasoni, D., Mwanje, M.T, Ndayishimiye, O., Lwambo, N. JS., Mbotha, D., Karanja, P., Mwandawiro, C., Muchiri. E., Clements, A. CA., Bundy, D. AP. And Snow, R.W., 2009. An updated atlas of human helminth infections: The example of EastAfrica. International Journal of HealthGeographics. $\quad 8, \quad 1-11 . \quad$ DOI: https://doi.org/10.1186/1476-072X-8-42

Burrough, P.A. and McDonnell, R.A., 1998. Principles of Geographic Information Systems, 1998. Oxford ; New York : Oxford University Press.

CAICT [China Academy of Information and Communications Technology], 2020. Research Report on Data and Intelligent Application in Epidemic Prevention and Control (1.0). Accessed 29 June 2020.

CCDCP [Chinese Center for Disease Control and Prevention], 2020. The epidemiological characteristics of an Outbreak of 2019 Novel Coronavirus Diseases (COVID19) China.

CDC [Centres for Disease Control and Prevention], Accessed 29 June 2020.

Cheng, Y. J., Norris, J., Bao, C. J., Liang, Q., Hu, J.L., Wu, Y., Tang, F.Y., Liu, W.D., Ding, K. Q., Zhao, Y., Peng, Z. H., Yu, R. B., Wang, H., Shen. H. B. and Chen, F., 2012. Geographical information system-based spatial analysis and implications for syphilis interventions in Jiangsu province, People's Republic of China. Geospatial Health 7 (1), 63-72. DOI: https://doi.org/10.4081/gh.2012.105

Childs, C., 2004. Interpolating surfaces in ArcGIS spatial analyst. ArcUser, July-September, 3235, 569.

CPH [Census of Population and Housing] 2014.
Ding, K.Q., Bao, C.J., Hu, J.L., Liang, Q. and Lei, N., 2011. Spatial analysis of tuberculosis epidemic in Jiangsu province based on Geographic Information System, 2011. Chin J Public Health, 27, 1097-1099. DOI: https://doi.org/10.3201/1409.071543

Helene, G., Marie, G., Nicolas, M. and Annelise, T., 2010. Utilisation des systèmes d'information géographique en épidémiologie.

Holdaway, M.R.,1996. Spatial modeling and interpolation of monthly temperature using kriging. Clim Res 6: 215-225. DOI: https://doi.org/10.3354/cr006215

Jayakumar, K. and Malarvannan, S., 2013. Spatial mapping of cholera using GIS tools in Chennai, India, Arch. Appl. Sci. Res., 5(3):93-99.

Jerrett, M., Gale, S. and Kontgis, C., 2010. Spatial modeling in environmental and public health research. Int. J. Environ. Res. Public Health, 7, 1302-1329. DOI: https://doi.org/10.3390/ijerph7041302

Johnston, K., Hoef, V. J. M., Krivoruchko, K. and Lucas, N., 2004. Using ArcGIS geostatistical analyst environmental systems research, Redlands, U.S.A., 114.

Katharina, H., Marius, A. and Edzer. P., 2011. Spatial interpolation in massively parallel computing environments. AGILE, April 18-22.

Kawo, N. S. and Karuppannan, S., 2018. Groundwater quality assessment using water quality index and gis technique in Modjo River Basin, Central Ethiopia. Journal of African Earth Sciences, 147, 300-311. DOI: https://doi.org/10.1016/j.jafrearsci.2018.06.034

Kheirandish, S., Liaghat, M., Azahar, T. M. and Gohari, A., 2012. Comparison of interpolation methods in prediction the pattern of basal stem rot diesease in palm oil plantation. Geoinformatica - An International Journal (GIIJ), 2(1):12-16.

Krige, D.G., 1966. Two dimensional weighted moving average trend surfaces for ore-evaluation. Journal of the South African Institution of Mining and Metallurgy, 66: 13-38.

Kurtzman, D. and Kadmon, R., 1999. Mapping of temperature variables in Israel: A comparison of different interpolation methods. Clim Res 13, 33-43. DOI: https://doi.org/10.3354/cr013033

Laborde, J. P., 2000. Méthodes d'interpolation et géostatistiques pour la cartographie automatique. Université de Nice, Sophia Antipolis, CNRS-UMR, 5651, 27.

Lyseen, A. K., Nøhr, C., Sørensen, E. M., Gudes, O., Geraghty, E. M., Shaw, N. T. and Tellez, C. B., 2014. A review and framework for categorizing current research and development in health related Geographical Information Systems (GIS) Studies. IMIA Yearbook of Medical Informatics, 9(1), 110-24. DOI: https://doi.org/10.15265/IY-2014-0008

Maged, N., Boulos, K. and Estella, M. G., 2020. Geographical tracking and mapping of coronavirus disease COVID$19 /$ severe acute respiratory syndrome coronavirus 2 (SARS-CoV-2) epidemic and associated events around the world: How 21st century GIS technologies are supporting the global fght against outbreaks and epidemics, International Journal of Health Geographics. DOI: https://doi.org/10.1186/s12942-020-00202-8

Matheron, G., 1963. Principles of geostatistics. Economic Geology, 58, 1246-1266. DOI: https://doi.org/10.2113/gsecongeo.58.8.1246

MMH [Moroccan Ministry of Health]. Accessed 16 July 2020. 
Ouhsine, O., Ouigmane, A., , Layati, El., Aba, B., Isaifan, R.J. and Berkani, M., 2020. Impact of COVID-19 on the qualitative and quantitative aspect of household solid waste. Global J. Environ. Sci. Manage, 6(4). DOI: https://doi.org/ 10.22034/GJESM.2019.06.SI.05

Qayssar, M. A., Muntadher, A. S., Nihad, D. H., Sumaya, F. H. and Noori, A.M., 2018. GIS based spatial modeling to mapping and estimation relative risk of different diseases using inverse distance weighting (IDW) Interpolation Algorithm and Evidential Belief Function. International Journal of Engineering \& Technology, 7(4.37); 185-191.

Quenum, M., 2009. Cartographie à l'échelle de la parcelle agricole de variables indicatrices de la capacité des sols à fixer le phosphore à l'aide de la télédétection et des nouvelles technologies. Université du Québec, INRSETE, Thèse dotorale, 16-20.

Robinson, T. P. and Metternicht, G., 2003. Optimal spatial interpolation of soil properties to assist precision agriculture. Conf. Spatial Sciences. ACT.

Schreider, S.Y., Whetton, P.H., Jakeman, A.J. and Pittock, A. B., 1997. Runoff modeling for snowaffected catchments in the Australian alpine region, eastern Victoria. Journal of Hydrology 200(1-4), 1-23. DOI: https://doi.org/10.1016/S0022-1694(97)00006-1

Shaw, N. T., 2012. Geographical information systems and health: current state and future directions. Healthcare Informatics Research, 18, 88-96. DOI: https://doi.org/10.4258/hir.2012.18.2.88

Shrikant, P., Aditya, S., Mamata, C. and Durga, R., 2020. Effects of temperature on COVID-19 transmission. DOI: https://doi.org/10.1101/2020.03.29.20044461
Tian. S., Hu, N., Lou, J., Chen, K., Kang , X., Xiang, Z., Chen, H., Wang, D., Liu, N., Liu, D., Chen, G., Zhang, Y., Liu, D., Li, J., Lian, H., Niu, S., Zhang, L., Zhang, J., 2020. Characteristics of COVID-19 infection in Beijing. Journal of Infection 80, ISSUE 4, 401-406. DOI: https://doi.org/10.1016/j.jinf.2020.02.018

Victor, A.O., 2020. Mathematical predictions for covid-19 as a global pandemic, SSRN. https://doi.org/10.1101/2020.03.19.20038794

WHO [World Health Organization], 2020. Coronavirus disease (COVID-2019) situation Reports. Accessed 16 July 2020.

Willmott, C.J. and Matsuura, K.,1995. Smart interpolation of annually averaged air temperature in the United States, 1995. J Appl Meteorol 34, 2577-2586. https://doi.org/10.1175/15200450(1995)034<2577:SIOAAA>2.0.CO;2

Zhiqiang, L., Jianming, W., Junyu Z, Haitao, L., Baoqing, L., Jie, S., and Chunlei, Z.,2008. The statistical meaning of kurtosis and its new application to identification of persons based on seismic signals. Sensors, 8, 5106-5119. DOI: https://doi.org/10.3390/s8085106

Zhou, C., Su, F., Pei, T., Zhang, A., Du, Y., Luo, B., Cao, Z., Wang, J., Yuan, W., Zhu, Y., Song, C., Chen, J., Xu, J., Li, F., Ma, T., Jiang, L., Yan, F., Yi, J., Hu, Y., Liao, Y. and Xiao, H.,2020. COVID-19: Challenges to GIS with big data. Geography and Sustainability. DOI: https://doi.org/10.1016/j.geosus.2020.03.005 